\title{
Postpartum ovarian vein thrombosis and renal vein thrombosis in a woman with protein $S$ and $C$ deficiency
}

\author{
Selma Guler, ${ }^{1}$ Omer Faruk Kokoglu, ${ }^{1}$ Hasan Ucmak, ${ }^{1}$ Fuat Özkan ${ }^{2}$
}

\begin{abstract}
1 Department of Infectious Disease, Faculty of Medicine, Kahramanmaras, Turkey ${ }^{2}$ Department of Radiology, Sütçü Imam University, Kahramanmaras, Turkey
\end{abstract}

Correspondence to Dr Selma Guler, selmaguler38@hotmail.com

\section{DESCRIPTION}

A 24-year-old woman was admitted to our hospital with high fever and poor general status developing 7 days after emergent caesarean section was performed because of the premature rupture of the membranes. She was admitted to the intensive care unit with a diagnosis of sepsis. Her history revealed one abortus and one stillbirth and no endometriosis. She was dehydrated, with shivering, tachycardia and hypotension. Her alanine transaminase, aspartate aminotransferase, bilirubin, blood urea nitrogen and creatine levels were mildly elevated. Teicoplanin and imipenem were given in adjusted renal doses. Fever reincreased at thetenth day of hospitalisation, and a pain in the left paravertebral region appeared. Contrast-enhanced abdominal CT revealed thrombosis of the left ovarian vein with extension into the left renal vein and inferior caval vein (figures 1 and 2). Protein $C$ and $S$ deficiency was found, and warfarin and enoxaparin were started. The patient was discharged uneventfully.

Postpartum ovarian venous thrombosis occurs in about 1600-12000 deliveries. ${ }^{1}$ Among its risk factors is endometritis, but sometimes there is no obvious cause. The left ovarian vein usually drains into the proximal left renal vein, which explains the coincidental left venous thrombosis in this case. The thrombus extending into the inferior cava is associated with a high risk of pulmonary embolism, but fortunately this did not happen. In this case, ovarian thrombosis may have evolved by the coincidence of different risk factors, one of which is protein $\mathrm{S}$ and $\mathrm{C}$ deficiency. It is seen rarely $(0.2 \%)^{2}$

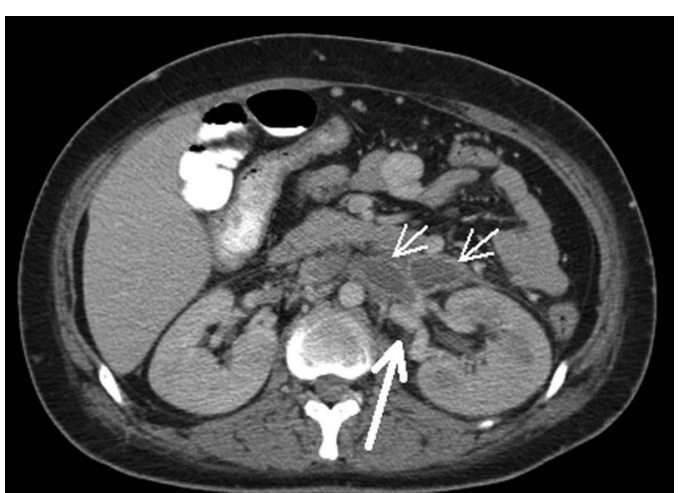

Figure 1 Axial contrast-enhanced CT shows a low-attenuating thrombus in the renal vein and ovarian vein (short arrows), in addition to indirect renal findings include renal enlargement with persistent parenchymal opacification and venous collaterals (thick arrow).

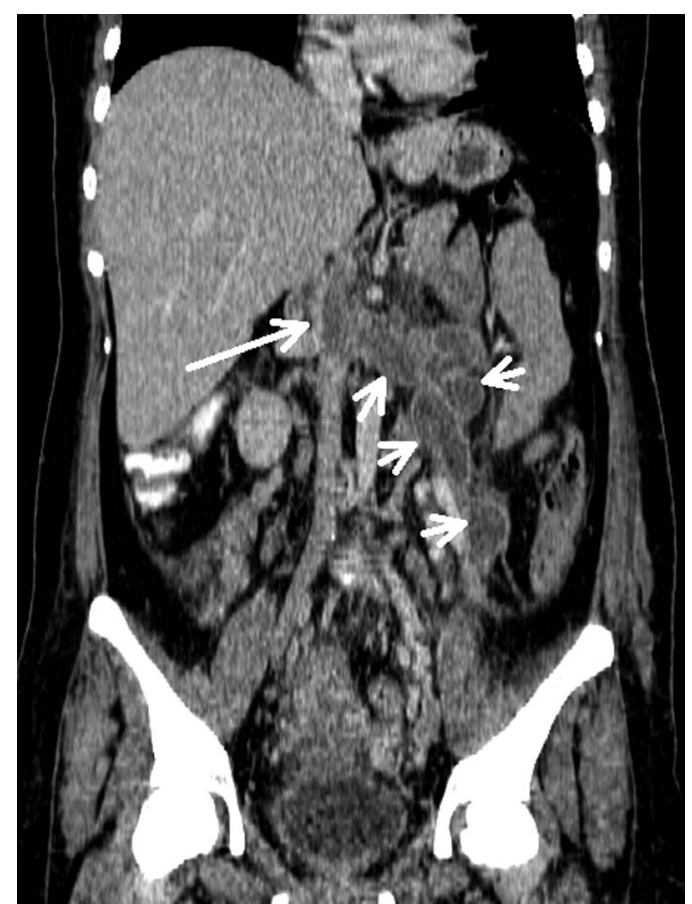

Figure 2 Coronal reformatted image of contrast-enhanced abdominal CT shows enlarged tortuous thrombosed left ovarian vein, drains into the left renal vein which drains into the inferior caval vein (arrows). CT also reveals thrombus extending from the left renal vein into the inferior vena cava (long arrow)

Renal vein thrombosis should be kept in mind in patients developing sudden abdominal or paravertebral pain and high fever.

\section{Learning points}

- Ovarian vein thrombosis and renal vein thrombosis are rare. They may present with high fever, paralumbar pain and leukocytosis or they may be asymptomatic.

- Patients with thrombophilia may have an underlying coagulopathy, such as the rare protein $\mathrm{S}$ and $\mathrm{C}$ deficiency, so that accordingly laboratory studies may be useful.

Competing interests None.

Patient consent Obtained.

Provenance and peer review Not commissioned; externally peer reviewed. 


\section{Images in...}

\section{REFERENCES}

1 De Stefano V, Martinelli I. Abdominal thromboses of splanchnic, renal and ovarian veins. Best Pract Res Clin Haematol 2012;25:253-64.

Copyright 2013 BMJ Publishing Group. All rights reserved. For permission to reuse any of this content visit http://group.bmj.com/group/rights-licensing/permissions.

BMJ Case Report Fellows may re-use this article for personal use and teaching without any further permission.

Become a Fellow of BMJ Case Reports today and you can:

- Submit as many cases as you like

- Enjoy fast sympathetic peer review and rapid publication of accepted articles

- Access all the published articles

- Re-use any of the published material for personal use and teaching without further permission

For information on Institutional Fellowships contact consortiasales@bmjgroup.com

Visit casereports.bmj.com for more articles like this and to become a Fellow 